\section{Model Matching Approach in RF Power Amplifier Linearization}

\author{
Prof. Dr.-Ing. Lothar Schüssele \\ Fakultät Elektrotechnik \\ und Informationstechnik ( $E+l)$ \\ Studiendekan Communication \\ and Media Engineering (CME) \\ Badstraße 24, D-77652 Offenburg \\ Tel.: 0781 - 205296 \\ E-Mail: I.schuessele@fh-offenburg.de
}

1971 -1978: Studium der Elektrotechnik an der Universität Karlsruhe mit den Schwerpunkten Hochfrequenztechnik und Quantenelektronik 1978-1984: Wissenschaftlicher Mitarbeiter am Lehrstuhl für Theoretische Elektrotechnik und optische Nachrichtentechnik der Universität Kaiserslautern

1984: Promotion auf dem Gebiet der optischen Nachrichtentechnik 1984-1986: Firma Inovan, Pforzheim; Entwicklung von Verfahren zur Materialbearbeitung mit Lasern

1986-1989: Firma Dornier GmbH, Friedrichshafen

Projektmanagement im Bereich Raumfahrt-Großprojekte

01.04.1989: Berufung an die Fachhochschule Offenburg für die Lehrgebiete Hochfrequenztechnik, Mikrowellentechnik und optische Nachrichtentechnik

Forschungsgebiete: Hochfrequenztechnik, Elektromagnetische Verträglichkeit

\section{Prof. Dr. Mario Magaña \\ School of Electrical Engineering and Computer Science \\ Oregon State University}

Badstraße 24, D-77652 Offenburg Tel.: 0781 - 205296

E-Mail: I.schuessele@fh-offenburg.de
1980-1982: Harris Corporation, Melbourne and Boing Company, Seattle

Seit 1989: Associate Professor at Oregon State University Researcher and Lecturer in Germany at University UIm, University Stuttgart, Hochschule Offenburg

Forschungsgebiete: Hochfrequenztechnik, Elektromagnetische Verträglichkeit

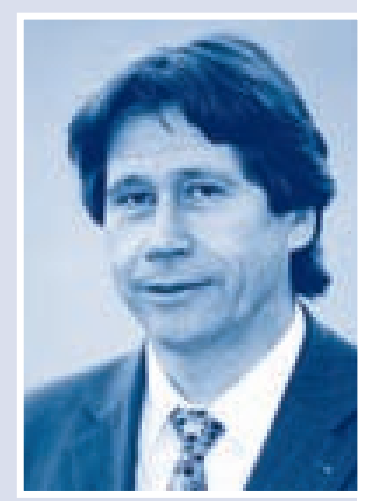

E-Mail.I.schuessele@fh-offenburg.de

\subsection{Model Matching Approach in RF Power Amplifier Linearization}

Lothar Schüssele

Prof. Dr. Mario E. Magaña [1]

Robert Bogya

\section{Kurzfassung}

Radio frequency (RF) power amplifiers (PA) are the most power consuming components of a mobile communications unit. They are used to convert the DC power from the battery into RF power delivered to the antenna. In a cell phone it becomes very important to use highly efficient power amplifiers, such as Class C and Class E PAs, to increase the talk time which is directly proportional to the battery life. On the other hand, these RF PAs are inherently nonlinear and produce spectral regrowth and other undesirable effects. Therefore, to exploit their high efficiency, it is desirable to employ linearization techniques to linearize their overall response. Linear model matching linearization techniques are investigated in this work to compensate for PA nonlinearities. The application of theses techniques results in a controller architecture that delivers excellent linearity performance of compensated Class C PA models, making

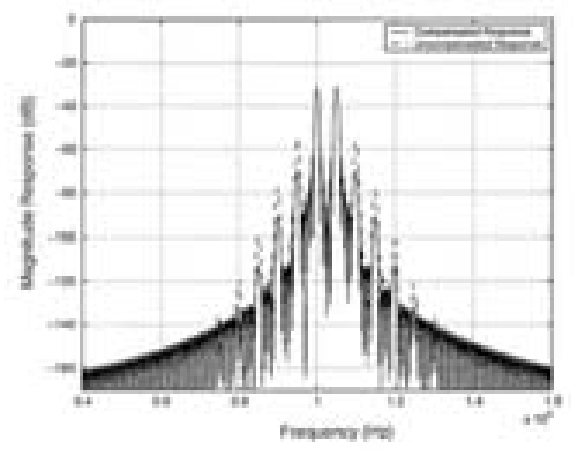

Fig. 1.6-1: Two-tone test results

them very suitable in wideband digital communication systems that transmit multiple signals at high data rates, assuring that intermodulation distortion and spectral regrowth are minimized at the output of the power amplifier.

Figure 1.6-1 shows the result of a TwoTone Test. The magnitude response plots of the uncompensated and compensated models are shown.

The third order products in the compensated case are suppressed significantly, at least by $18 \mathrm{~dB}$ and the fifth order intermodulation products are suppressed by $16 \mathrm{~dB}$.

The improvement of noise behavior is shown in Figure 1.6-2, considering the

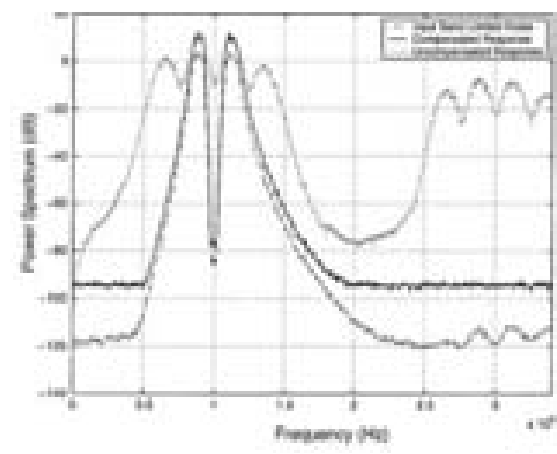

Fig. 1.6-2: White noise test with the model matching approach

result of the white noise test. The power spectra of the input and of the output of the uncompensated and compensated models are shown. The spectrum of the output band-limited noise, in the compensated case, preserved the deep notch in the middle of the spectrum, whereas in the uncompensated case the notch was filled-in significantly. This test also proves the linear behavior of the compensated power amplifier.

[1] Prof. Dr. Mario Magaña from the Oregon State University, USA, has been at the University of Applied Science Offenburg in the summer semester 2008 for research and teaching. 